\title{
§ 32a Besondere Zuständigkeiten
}

Die Bearbeitung von Meldungen der für die Kontrolle der Außengrenzen zuständigen Behörden über Aussetzungen gemäß Artikel 27 Absatz 3 Satz 1 der Verordnung (EG) Nr. 765/2008 des Europäischen Parlaments und des Rates vom 09.07.2008 über die Vorschriften für die Akkreditierung und Marktüberwachung im Zusammenhang mit der Vermarktung von Produkten und zur Aufhebung der Verordnung (EWG) Nr. 339/93 des Rates (ABl. L 218 vom 13.08.2008, S. 30) obliegt der Überwachungsbehörde, die für die Zollstelle örtlich zuständig ist.

(ohne Kommentierung) 